\title{
Mob Ideology or Democracy: Analyzing Taiping Rebellion's Defeat and Revolution of 1911's Triumph in Ending the Qing Dynasty
}

\author{
Bincheng Mao \\ New York University
}

\section{Introduction}

The Collapse of the Qing Dynasty in 1912 marked one of the most consequential geopolitical changes in the contemporary history of East Asia, and historians often connect this dynasty's crumbling to both the Taiping Rebellion in the 1850s as well as the Xinhai Revolution in 1911. The ferocious Taiping Heavenly Kingdom Movement was undoubtedly a significant event in modern Chinese history. Led by Hong Xiuquan, this armed rebellion persisted for over 14 years, covering 18 provinces; yet the Qing Dynasty lived on. On the contrary, the Xinhai Revolution of 1911, within four months and fifteen days, achieved the objective that Hong Xiuquan could not attain in fourteen years: overthrowing the Qing Dynasty. Therefore, it is particularly meaningful to investigate a core question: why did the Qing Dynasty survive the Taiping Rebellion yet crumbled upon the Revolution of 1911? In this paper, the author argues that the Qing dynasty survived the Taiping Rebellion yet crumbled upon the Xinhai Revolution because the latter's core ideology, Three Principles of the People, drew support from within the Qing regional governments by creating the prospect of maintaining power for Qing officials, while the Taiping Rebellion's mob ideology achieved the contrary; in addition, the Revolution of 1911 faced a weakened imperial dynasty due to its internal conflicts over constitutional reforms, successfully prevented foreign powers from aiding the imperial dynasty — two conditions absent for the Taiping Rebellion. 


\section{Differences in Ideologies Between the Taiping Rebellion and the Revolution of 1911}

\subsection{Taiping Rebellion's Counterproductive Mob Ideology}

Even though members of the Taiping Rebellion claimed to be champions of "God," it was, in fact, a facade used to conceal the reality that they were merely driven by a self-serving mob ideology; it was this very ideology that doomed the rebellion to ruin as it cut off its hope to break the Qing dynasty from the inside. According to Chinese Among Others: Emigration in Modern Times by historian Philip A. Kuhn, from 1753 to 1832, China experienced a period of rapid population growth, leading to "a $43 \%$ decrease of cultivated area per capita." 1 In other words, every Chinese farmer lost nearly 8 acres of arable land, causing a substantial increase in famines throughout China, especially in the South where the population boomed. This was the condition that the ordinary Chinese people were in.

Taking advantage of the situation of famine and poverty, Hong Xiuquan, the leader of the Taiping Rebellion, offered the people a religion whose creeds included "people who believe in other religions give joy up to ask for pain," and "faithful followers shall receive all food as presents from the "God Emperor," whom Hung claimed to be his father in his publication Instructions on the Original Way to Save the World. ${ }^{2}$ Those farmers and workers who had long suffered from food shortages under the Qing dynasty's rule had no idea who this "God Emperor" was but were quite interested in acquiring food and pleasure. Therefore, more and more people, who had only been exposed to Chinese folk religions previously, joined the Taiping Army not because of their devout religious faith in Hung's newly formed God Worshipping Society but to acquire food and other resources they desperately needed, hence their mob ideology.

The mob ideology of the Taiping Rebellion resulted in their looter-like characteristics: when the Taiping Army occupied a city, the surrendered, including both Qing officers and civilians, would be slaid by mod-like Taiping soldiers and their property would be taken away. For instance, according to What Happened in Nanking in 1853 by Shen Juanxi, a survivor of the Taiping Army's massacre after the 1853 battle of Nanking, following Taiping's capture of the historic city, "there were civilians' bodies all over the streets while soldiers forced yet-to bekilled local people to hand in their wealth by putting machetes on their necks." 3 Massacres that resemble horror in Nanking in 1853 repeatedly occurred during the Taiping Rebellion yet the leadership never sought to stop them, proving that both the lower and upper-level members of the rebellion prioritized satisfying themselves rather than to establish a "heavenly kingdom" under Hung's religious teachings.

In addition, this mob ideology led to the ultimate failure of the Taiping Rebellion because it unintentionally united Qing regional officers against a common enemy in order to preserve their lives and property. In other words, this mob ideology made it impossible for senior Qing officials, who possessed enormous fortune, to join the rebellion, causing the slow expansion of

\footnotetext{
${ }^{1}$ Philip Kuhn, Chinese Among Others: Emigration in Modern Times (London: Forgotten Books, 1987), 79.

${ }^{2}$ Xiuquan Hong, Instructions on the Original Way. (Nanjing: Nanking Publishing House, 1940), 35.

${ }^{3}$ Juanxi Shen, What Happened in Nanking in 1853 (Nanjing: University of Nanking Press, 1899), 83.
} 
the Taiping Heavenly Kingdom and earning time for the mobilization of Qing dynasty forces. For example, Bao Lishen, a member of the gentry in Bao Town of Zhejiang Province, led his men to fight against the Taiping Army invasion for nearly a year, "killing more than thirteen thousand Taiping soldiers and holding no fewer than ten thousand of them as captives" according to the research paper "Conflicts Between the Taiping Army and Local Forces" by Dr. Liu Chen. While the battles in Bao Town inflicted heavy losses on the Taiping forces, the Qing dynasty's Viceroy of Lianxiang, Zeng Guofan, also realized that the Taiping Army, characterized by its mob ideology, is life-threatening to him. As recorded in William Rowe's China's Last Empire: the Great Ching, Zeng organized the Xiang Army from "existing regional militia forces to suppress the Taiping Rebellion."5 By 1859, Zeng Guofan's army, aided by gentry like Bao Lishen, recovered much of Zhejiang province from the Taiping Heavenly Kingdom, displaying the unintended consequence of Taiping's mob-like mentality of consolidating Qing's regional forces.

2.2 Revolution of 1911: The San-min Doctrine (Three Principles of the People) That Broke Down the Qing Dynasty

Unlike the Taiping Rebellion, the Revolution of 1911 possessed a clear and rational guiding ideology, the San-min Doctrine, also known as the Three Principles of the People; this was this very ideology that incited the defection of multiple Qing regional officials by giving them hopes of preserving and even expanding their powers, therefore resulting a dramatic shift in power between the imperial and revolutionary forces.

The Revolution of 1911 was led by the Chinese United League, or Tongmenghui, a merger of multiple revolutionary societies in the late Qing dynasty. The league, headed by Sun Yat-sen, held a central faith, the San-min Doctrine, an ideology consisting of three aspects: nationalism (Mínzú), people’s power (Mínquán), and people’s livelihood (Mínshēng). The founder, Sun Yat-sen, constructed these three principles based on US President Abraham Lincoln's Gettysburg address, "a government of the people" corresponds to "Minzu", "a government by the people" corresponds to "Mínquán," and "a government for the people" corresponds to "Mínshēng." After the formation of this ideology, Sun Yat-sen spared no effort to promote it. According to Sun Yat-sen: His Life and Its Meaning published by Stanford University Press, Sun "announced all three principles in the spring of 1905" and then gave

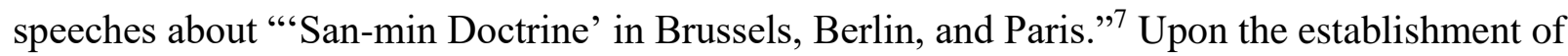
Tongmenghui, Sun published multiple editorials in domestic newspapers, such as Min Bo, to advocate for the three principles throughout China.

\footnotetext{
${ }^{4}$ Liu Chen, "Conflicts Between the Taiping Army and Local Forces" (Beijing: The Qing History Journal, 2003), 15.

${ }^{5}$ William T. Rowe, China's Last Empire: the Great Ching (Cambridge: Harvard University Press, 2004), 137.

${ }^{6}$ Lyon Sharman, Sun Yat-sen: His Life and Its Meaning, a Critical Biography (Palo Alto: Stanford University Press, 1974), 94.

${ }^{7}$ Ibid., 103.
} 
In the case of the Revolution of 1911 specifically, the second principle of the San-min Doctrine, Mínquán, was the deciding factor in the revolution's success. According to The Three Principles of the People written by Sun Yat-sen, the principle of Mínquán, literally "people's power," is divided into two parts: "the power of politics and the power of governance." 8 The "power of politics" is the citizens" power to express their political will through four methods: "election, recall, initiative, and referendum." "When merely considering this first set of power, it may even seem counter-productive to gain support from Qing officials since measures, such as recall and election, would put limits on their power. However, when factoring in the second set of power, "the power of governance," the boost that this ideology brought to the revolution becomes much more intelligible. The "power of governance," as Sun Yat-sen puts it, is the "power of administration." "It allows officials to make policies in order to govern the very people who are supposed to be their source of power. On top of this, without laws or rules that limit regional officials' power at the moment, they were virtually free to maintain their ruling status by regulating commerce and the media to control the public, canceling out the checks established in the "power of politics." Moreover, according to Electoral History of the Republic of China, the 1911 Provisional Presidential Election set up by the revolutionists was not a general election but an indirect one in which "Sun Yat-sen was elected president by representatives of governors from seventeen provinces." 11 And according to the roster of governors, Cheng of Jiangsu Province, Zhu of Shandong Province, Zhang of Guangxi and Guangdong Province and three others were all governors of their respective provinces in the Qing dynasty and joined the revolutionists in $1911 .^{12}$ Their preservation of the governorship proves the probabilities for Qing regional officials to preserve their political powers under the new government. The fact that the San-min Doctrine grants officials the power to govern and the government guided by such ideology allowed former Qing officials to preserve powers rather than ousting all of them are evidence of how the Revolution of 1911 greatly differs from the Taiping Rebellion half a century ago.

\section{The Impact of Foreign Intervention on the Outcomes of the Taiping Rebellion and the Revolution of 1911}

3.1 Foreign Aid to the Qing Dynasty that Doomed the Taiping Rebellion

Other than their ideological differences, the intervention of foreign powers favoring the Qing dynasty was also a core factor that determined the failure of the Taiping Rebellion. During the initial stage of the revolt, foreign powers were interested in this self-proclaimed Christian-led rebellion in China because of its potential to convert over 400 million Chinese into Christians.

\footnotetext{
${ }^{8}$ Sun, Yat-sen, Three Principles of the People (Shanghai: Jiuzhou Publishing House, 2011), 21.

${ }^{9}$ Ibid., 22.

${ }^{10}$ Ibid., 27.

${ }^{11} \mathrm{Wu}$, Po-hsiung, Electoral History of the Republic of China, (Central Electoral Commision Publishing, 1987), 45.

12 Ibid., 46.
} 
Soon after the Taiping Heavenly Kingdom established its capital in Nanking 1853, many western powers sent their plenipotentiaries to visit Hung, the heavenly king, including Sir. George Bonham, the British Minister Counselor to China in 1848-1854. According to The Chinese and Their Rebellions by Thomas Taylor Meadows, the assistant of Bonham, the minister counselor was shamed by the arrogant ruler of the Heavenly Kingdom. The Englishman not only found that Hung asked "England to be a client state of the Taiping Heavenly Kingdom," but also that the Taiping leadership lived extravagant and dissipated lives, often the exact opposite to his Christian ideals. ${ }^{13}$ Upon Sir. Bonham's return to London, he casted serious doubts on the Christian nature of the Taiping Rebellion and its capability to replace the Qing dynasty as China's ruling authority, suggesting London and other European powers not to support the Taiping regime. ${ }^{14}$

The beauty of historical research is to discover previously ignored relationships between critical events in history, and the fact that England did not support the Taiping Army in its earlyto-mid stages, while it still prevailed, also had such a fascinating connection. On October 16th of the same year that the Taiping Army achieved its grand victory in Nanking, the Crimean War broke out in Europe. Over two hundred and fifty thousand British troops participated in the battles, resulting in appropriately seventeen thousand casualties. This massive loss in Crimea further reduced the British government's will to intervene in a lengthy Chinese civil war, hence Britain's, the most powerful imperial country at the time, neutral stance before 1860 .

However, in 1869, the Taiping Army made a move on Shanghai, center of the textile industry in China, after destroying most of the agricultural industries in the deep South, threatening the production of crucial commodities for the UK, such as tea and silk. Accordingly, London had to choose one between the Qing dynasty and the Taiping Rebellion to assist it in winning the civil war. Days before its planned siege of Shanghai, Taiping announced that it would ban the trade of opium, alcohol, and tobacco from foreign countries, hoping to gain popular support in Shanghai. Yet, this plan backfired. Following the Taiping regime's ban on opium business, Britain's primary source of profits in China, London considered the Qing dynasty to be the better facilitator of British interests. Then, in June of 1860, the UK government implemented restrictions on all arms sales to the Taiping Heavenly Kingdom according to The History of the Taiping Rebellion, while allowing British merchants to sell rifles and canons to the Qing Army. Since then, the Taiping Army could only obtain western weapons by smuggling, which was obviously much more costly and time-consuming. ${ }^{15}$ Foreigners in Shanghai, aided by their respective nations, also formed their own militia to resist the Taiping invasion. ${ }^{16}$ According to Henry Andres Burgevine, the co-commander of the "Ever-Victorious Army," a unit of foreign

\footnotetext{
${ }^{13}$ Thomas T. Meadow, The Chinese and Their Rebellions: Viewed in Connection with Their National Philosophy, Ethics, Legislation, and Administration (Cambridge: Cambridge University Press, 2015), 155.

${ }^{14}$ Ibid., 156.

${ }^{15}$ Augustus F. Lindley, The History of the Taiping Rebellion (London: CreateSpace Independent Publishing, 2012), 83.

${ }^{16}$ Henry A. Burgevine, The Ever Victorious Army: A History Of The Chinese Campaign Under Lieutenant Colonel C. G. Gordon And Of The Suppression Of The Tai-Ping Rebellion (London: Kessinger Publishing, 2010), 204.
} 
mercenaries working on behalf of the Qing dynasty to protect Shanghai, representatives of the Qing Army could buy a rifle for 15 to 20 silver dollars, a price much lower than usual while the sales to the Taiping Army was strictly prohibited. ${ }^{17}$ This meant that however much that the Taiping Army was willing to pay for western weapons, it was next to impossible for them to acquire them from the closest source of weapons in China.

\subsection{Limited Foreign Intervention during the Revolution of 1911}

If the Qing dynasty successfully suppressed the Taiping Rebellion with the assistance of foreign powers such as Britain, why did not the same outcome reappear in 1911? Primarily, the leader of revolutionists, Sun Yat-sen learned the lessons from the Taiping Rebellion's defeat and took a much more practical approach towards foreign interests in China. Sun never explicitly declared that the revolutionary government would withdraw from all unequal treaties with imperial powers or suspend foreign special interests in China. The revolutionist hoped to prevent foreign intervention and to acquire recognition from the international community. Therefore, a replacement of the Qing dynasty with the revolutionary republic hardly affects the interests of foreign powers in China.

In addition, foreign intervention existed during the time of the Revolution of 1911 but not during the Taiping Rebellion: the constraint of each other among great powers. During the historical period of the Taiping Rebellion, there were only two great foreign powers, Britain and France, that were capable of influencing the outcome of a Chinese civil war. Nevertheless, the distribution of power among nations altered dramatically half a century later in 1911: the power of the United States and Russia rose, and Germany and Japan also joined the world arena 。 These powerful countries had sharp conflicts of interests among themselves - 1911 was only three years before the first World War. According to The Origin Of Rebellions by Professor Xiang Lanxin, diplomats deployed by those powerful nations to China were not dealing with the affairs of China but rather the affairs of other powerful nations in China. ${ }^{18}$ The only thing these imperial states had in common was that they would never allow another to expand its interests in China alone. For example, in October 17th of 1911, Saidou Makoto, then Japanese naval minister, ordered the third fleet of Japan to block the Yangtze River in order to intervene in the Chinese Civil War of 1911, but London warned Tokyo not to take any action in China alone, forcing Japan to halt. ${ }^{19}$ Under this circumstance, The U.S., supported by France and Germany, proposed that all foreign powers may only take actions together in China, and the proposal was agreed by other countries soon on a meeting held in Washington D.C, forming "the principle of collective action." ${ }^{20}$ Therefore, as illustrated above, the complex situation in China in 1911 is

\footnotetext{
${ }^{17}$ Burgevine, The Ever Victorious Army, 207-212.

${ }^{18}$ Lanxin Xiang, The Origin of Rebellions (Tianjin: Tianjin University Press, 2011), 211.

${ }^{19}$ Ibid., 224.

${ }^{20}$ Ibid., 225.
} 
also an important reason that all those countries hold their neutral position steadily, allowing the Xinhai revolution to ultimately overturn the Qing dynasty.

\section{Different Circumstances that the Qing Government Was Under Between 1850s to 1910s}

\subsection{Taiping Rebellion and a Qing Government Without Significant Internal Conflicts}

Prior to the outbreak of the Revolution of 1911, a newly emerged class of national capitalists sought to expand their power by pushing for a transition of governing systems from an absolute monarchy to a constitutional monarchy, dividing the Qing leadership. And this division only occurred after the Taiping Rebellion as the rebellion is part of the reason that the Qing dynasty realized its need for a westernization movement which led to the rise of national capitalists and then their struggles towards constitutional reform.

The emergence of constitutionalists originated in the rise of capitalists as a result of the Self-Strengthening Movement beginning in the 1860s. Half a century before the Revolution of 1911, the Qing dynasty experienced the Taiping Rebellion, which it ultimately defeated with the help of foreign aid, and the Second Opium War, in which two western powers overwhelmed the Chinese imperial forces. After these two upheavals, the senior-level officials of the Qing dynasty acknowledged the superiority of western technologies yet were reluctant in recognizing the need for political reforms. In 1864, then-governor of Jiangsu Province, Li Hongzhang submitted a report to the Qing government, claiming that "the grand Chinese civil and military systems are significantly more advanced than those of the west, it is merely Chinese firearms that lags far behind." ${ }^{21} \mathrm{Li}$ later became one of the chief architects of the Self-Strengthening Movement and the aforementioned therefore became the manifestation of the movement's goal: to westernize the Qing dynasty's technological industry. During this time, the Qing government established the Jianan and Tianjin Arsenals, the Fuzhou Naval Yard, the Jiangnan Manufacturing Administration, etc. all of them are state-owned westernized industries. ${ }^{22}$ Therefore, a new class of national capitalists had not fully emerged in China due to the state-led nature of westernized industries.

However, this situation changed completely in 1894. The Qing Dynasty's most westernized and most trusted naval fleet was devastated in the First Sino-Japanese War. The pride of the imperial governing system rooted in traditional Sinocentrism shattered as the Qing dynasty, fully equipped with westernized technologies, lost to a none-western power, Japan. Since then, Qing began to open up its western industry to nationals and private companies, led by a class of capitalists, emerged. On top of this, the nation that defeated the Qing dynasty also had a westernization movement, the Meiji Restoration, where it not only westernized its technologies but also its governing system. By this point, the Qing government loosened its control on industries, allowing more individuals to participate. For example, in 1901, under the invitation of

\footnotetext{
${ }^{21}$ Hong Zhang Li, Original Letter from Jiangsu Governor to Zongli Yamen (Beijing: Xinyuan Publishing, 2013), 4.

${ }^{22}$ Steven A. Leibo, Transferring Technology to China: Prosper Giquel and the Self-Strengthening Movement (London: Institute of East Asian Studies, 1985), 69.
} 
the governor of Jiangsu Province, Zhang Jian, a private industrialist established modernized textile mills, oil plants, power plants, the province "gradually becoming an industrial powerhouse in China." ${ }^{23}$ Zhang, who accumulated a tremendous amount of wealth while receiving the rank of third-class state minister in the process, became a prominent constitutionalist. The reason that many industrialists with capital in the late Qing dynasty is that they wished to advance their political power after achieving financial successes. According to East Asia: A Cultural, Social, and Political History, traditional Confucianism ranked occupations from the highest to the lowest as "gentry officials, peasant farmers, craftsmen, and merchants." 24 Consequently, wealthy businessmen had long attempted to raise their social status by converting their financial capital into political power. Historically, their method was to purchase titles from governmental officials, yet these titles often came without any real power. The Westernization Movement in the late Qing dynasty gave them hope of acquiring such power; the influx of western information combined with Qing's defeat to a politically westernized Japan allowed these industrialists to push for a constitutional monarchy. Thereby, these industrialists, who were almost all ethnically Han, may have the chance to break the monopoly of power by the Manchurian royals. And inevitably, this would incur an internal conflict as the absolute monarchist fought back to perverse their power.

\subsection{Revolution of 1911: A Qing Government Weakened by Internal Conflicts Between} Constitutionalists and Absolute Monarchist

During the Revolution of 1911, the Qing dynasty was weakened by this internal conflict between the constitutionalists and absolute monarchists, for the monarchists' strong resistance against this political reform pushed constitutionalist officials to lose hopes of getting political power in the Qing dynasty and therefore flipped to the revolution. One of the key turning points in the Xinhai Revolution was the defection of the Qing dynasty's Jiangsu Governor, Dengquan Cheng, twenty-five days after the outbreak of the Wuchang Uprising. Prior to his defection, senior Qing officials were still reluctant in joining the revolutionists due to fears of losing their property, power, or lives. Yet, the fact that Cheng, the first provincial-level Qing official to join the revolution, was immediately reinstated as governor by the revolutionists encouraged more and more provincial leaders to leave the side of the Qing dynasty. Within a week after Cheng's defection, "Governor Bingkun Shen of Guangxi Province, Governor Jiabao Zhu of Anhui Province, Viceroy Mingqi Zhang of Guangxi and Guangdong, and Governor Baoqi Sun of Shandong Province" all declared independence from the Qing dynasty according to The Revolution of 1911: Turning Point in Modern Chinese History. ${ }^{25}$ Therefore, examining the reason behind the first flipped governor becomes crucial. In the article "Considering the Yuan

\footnotetext{
${ }^{23}$ Leibo, Transferring Technology 84.

${ }^{24}$ Patricia B. Ebrey, East Asia: A Cultural, Social, and Political History (New York: Cengage Learning, 2013), 105.

${ }^{25}$ Dong, Cai Shi (2012). The Revolution of 1911:Turning Point in Modern Chinese History. Foreign Languages Press, 137.
} 
Shih-kai Commemorative Silver One Dollar" published by China Guardian, it was discovered that Governor Cheng "telegraphed the Qing court to reshuffle the cabinet, establish a constitution in order to counteract the revolution after the Wuchang Uprising"26 Yet, no evidence showed the Qing government replied. And "Cheng then declared independence from the Qing dynasty." 27 In fact, this is hardly the only event that connected Cheng to the constitutional movement. The governor not only fully supported aforementioned industrialist Zhang Jian's proposal to establish a constitutional monarchy and organize a responsible cabinet, but also listed his name on Viceroy of Manchuria Xiliang's petition to the throne on October 25, 1910, advocating for a political reform towards a constitutional monarchy and proving his constitutionalist identity accordingly. ${ }^{28}$ However, all these attempts failed as the royal government refused to set up a Parliament by 1911 which was explicitly written in the memorial. All these failures combined pushed Governor Cheng to lose hope of any real constitutional reforms in the Qing dynasty. Therefore, he flipped to the revolution in 1911, becoming the turning point of the Xinhai Revolution. Since then, an increasing number of senior officials left the Qing dynasty - the imperial dynasty lost its last supporters - making it merely a matter of time before its collapse.

\section{Conclusion}

The Qing dynasty managed to sustain its rule after the Taiping Rebellion since the revolted people lacked a guiding ideology that would draw support from within the Qing government. In fact, the mob-like ideology reflected in the rebellion united senior officials in the Qing government to defend their lives and social status. On top of this, the Taiping Rebellion also faced a Qing dynasty strengthened by foreign aid while the rebellion itself failed to secure favorable foreign intervention due to its insistence on an opium ban. Finally, severe internal conflicts that would weaken the Qing government during a domestic revolt did not come during the 1850 s as their appearances required an event like the Taiping Rebellion to trigger.

On the other hand, the Qing dynasty crumbled upon the Revolution of 1911 because the revolution's ideology appealed to the personal interests of senior Qing officials, breaking the imperial dynasty from the inside. Additionally, the leader of the revolution chose a practical approach in dealing with foreign power's interests in China and the mutual constraints of actions among foreign powers in China also appeared, limiting foreign intervention in the course of the war. At last, the internal conflict between the constitutionalists and the absolute monarchist broke out around the time of the Xinhai Revolution, further weakening the imperial dynasty.

\footnotetext{
${ }^{26}$ Emily Chang, "Considering the Yuan Shih-kai Commemorative Silver One Dollar," China Guardian, 3.

${ }^{27}$ Chang, "Yuan Shih-kai Silver One Dollar," 4.

${ }^{28}$ Kent Guy, Qing Governors and Their Provinces (Seattle: University of Washington Press, 2017), 139.
} 


\section{Bibliography}

Burgevine, Henry A. (2010). The Ever Victorious Army: A History Of The Chinese Campaign Under Lieutenant Colonel C. G. Gordon And Of The Suppression Of The Tai-Ping Rebellion, 204, 207-2012. Kessinger Publishing, 2010.

Chen, Liu, "Conflicts Between the Taiping Army and Local Forces." Beijing: The Qing History Journal, 2nd, no. 6 (December 2003), 15.

Chang, Emily. "Considering the Yuan Shih-kai Commemorative Silver One Dollar.” Beijing: China Guardian, 3rd, no. 5 (2011), 3-4.

Dong, Cai Shi (2012). The Revolution of 1911: Turning Point in Modern Chinese History, 137. Beijing: Foreign Languages Press, 2012.

Ebrey, Patricia B. East Asia: A Cultural, Social, and Political History, 105. London: Cengage Learning, 2013.

Guy, Kent. Qing Governors and Their Provinces, 139. Seattle: University of Washington Press, 2017.

Hong, Xiuquan. Instructions on the Original Way, 35. Nanjing: Nanjing University Publishing House, 1940.

Kuhn, Philip. Chinese Among Others: Emigration in Modern Times, 79. London: Forgotten Books, 1987.

Leibo, Steven A. Transferring Technology to China: Prosper Giquel and the Self-Strengthening Movement, 69, 84. New York: Institute of East Asian Studies, 1985.

Li, Hong Zhang. Original Letter from Jiangsu Governor to Zongli Yamen, 4. Beijing: Xinhua Publishing, 2013.

Lindley, Augustus F. (2012) The History of the Taiping Rebellion, 83. New York: CreateSpace Independent Publishing, 2012.

Meadow, Thomas T. The Chinese and Their Rebellions: Viewed in Connection with Their National Philosophy, Ethics, Legislation, and Administration, 155-156. Cambridge: Cambridge University Press, 2015.

Rowe, William T, China's Last Empire: the Great Ching, 137. Cambridge: Harvard University Press, 2004.

Sharman, Lyon. Sun Yat-sen: His Life and Its Meaning, a Critical Biography, 94, 103. Palo Alto: Stanford University Press 1968. 
Shen, Juanxi, What Happened in Nanking in 1853: An Updated Account, 83. Nanjing: Nanjing University Press, 1899

Sun, Yat-sen. Three Principles of the People, 21-22, 27. Shanghai: Jiuzhou Publishing House, 2011.

Wu, Po-hsiung. Electoral History of the Republic of China, 45-46. Taipei: Central Electoral Commision Publishing, 1987.

Xiang, Lanxin. The Origin of Rebellions, 211, 224-225. Tianjin: Tianjin University Press, 2011 